\title{
FOREIGN RAILWAY EVENTS IN 1902-03
}

The newer and more remote parts of the world in which industrial and commercial life is relatively little developed naturally constitute the field in which the problems of railway construction and development are among the leading questions of the day. The greater part of Africa, Asia, Australasia and South America lie in this field, to which part; of Continental Europe, North and Central America may be added. In countries like England, Germany, France and the United States, where railway development is practically complete, at least so far as main lines are concerned, the railway problem is primarily an administrative problem, involving the more perfect adjustment of the various interests in the matter of service and rates, and the establishment and maintenance of a more rational modus vivendi among the different carriers. In the former group of countries, financial, political and military considerations predominate, while in the latter these are generally subordinated to social and economic interests, although in a certain sense economic and social interests may be said to exercise a controlling influence over transportation affairs in all parts of the world.

Last year's railway developments in Africa illustrate the co-existence of all these classes of interests: social and economic, in employing the railways in the restoration of the territory devastated by war, and in developing the mineral and agricultural resources of both coast and inland regions; political and military, in the order in which original construction, extensions and improvements have been planned; financial, in the importance attached to the manner in which the necessary funds have been raised, and the control of railway financiering in general; administrative, in the changes in railway management and in the readjustment of relations among the different South African systems. During Colonial Secretary Chamberlain's visit in South Africa, few, if any, subjects received more frequent mention than the railway question. The clamor for lower railway rates as a means of reducing the excessive cost of living became irresistible. It was asserted that it cost less to transport certain commodities from North America over 1,500 miles of railway and thence by sea to [I2I] 
Delagoa Bay, than from Delagoa Bay to Johannesburg, a distance of 396 miles. At a banquet given in honor of Secretary Chamberlain at Ladysmith, the governor of Natal, in a powerful speech, admitted the necessity of a readjustment of the relations among the different South African systems with the view of lowering rates, and recommended the appointment of a non-partisan commission to consider the questions brought forward by him. On a similar occasion at Bloemfontein, it was officially announced that in order to allay the fears regarding the deflection of traffic from one colony to another as a result of contemplated extensions, the earnings of the Transvaal and Cape Colony railways should be pooled. The unsettled and unsatisfactory condition of South African railway affairs is largely due to the conflicting interests of the different colonies with respect to local and through traffic. The reported appropriation for railway purposes of $\$ 65,000,000$ out of the Transvaal loan, authorized by Parliament early in May, is expected to remove many of the existing intercolonial railway difficulties. The Bloemfontein conference recommended that all private contracts reserve to the government the right of expropriation of all railway property, control of the cost of construction and the profits of contractors, and the regulation of rates.

A request for a grant of $£ 600,000$ additional for the completion of the Uganda railway, bringing the total up to $£ 5,500,000$, or about $£ 9,500$ per mile, was the occasion of sharp debates in both Houses of the British Parliament during December and January. The Uganda railway extends from Mombasa on the Indian Ocean, about $4^{\circ}$ south of the equator, to Port Florence on Lake Victoria Nyanza, a little north of the equator. 'The entire line of 584 miles thus extends through a tropical belt, the greater part of which is said to be infested with malaria. Members of Parliament charged the government with extravagance and inefficiency, and demanded an explanation of the rejection of bids of private contractors offering to construct the railway at onehalf the amount expended by the government. The government justified the situation on the ground of unfavorable climatic conditions, excessive rains, scarcity of coal, and the importation of labor from India. Furthermore, other powers were moving in the direction of Uganda, and the future possibilities of the British East African protectorate, it was argued, amply justify 
the government's policy. Since then the Uganda railway has been opened for traffic and the reported earnings amount to $£ 3$ per mile per week. There are two through passenger trains weekly, connecting with two steamers built at Paisley, but erected on the shores of Victoria Nyanza, and capable of carrying I 2 firstclass and roo deck passengers. Potatoes, which were formerly imported into South Africa from Central America and Portugal, are being shipped there now at the rate of 40 to 50 tons per month from the territory served by the Uganda railway. The cost of transportation has been reduced along this route from $7 \mathrm{~s} .6 \mathrm{~d}$. per ton-mile, being the old caravan rate, to $2 \frac{1}{2} d$. per ton-mile by rail. However, the government will probably be obliged to meet a deficit for some years to come, on account of its Uganda enterprise.

Before the close of 1903 the South African Chartered Company will have expended $£ 2,000,000$ for railway purposes, onehalf for the completion of the line from Buluwayo to Victoria Falls, including a fine steel bridge over the Zambesi, and the construction of three branch lines varying in length from 25 to 100 miles in contiguous territory. The other $E_{\mathrm{I}, 000,000}$ are to be devoted to a continuation of the Cape to Cairo railway from Victoria Falls northward to the great bend in the Kafu River, a branch of the Zambesi, where valuable deposits of copper and lead have been discovered. The supreme grandeur of Victoria Falls is destined to make it a rival of Niagara in attracting tourists, a fact of which the interested railway authorities have by no means been unmindful. In the official report of his recent trip through Rhodesia, the secretary of the Chartered Company, after comparing the 2,193 miles of railway in Rhodesia with the 6 I 2 of Natal, 442 of Orange River, 895 of the Transvaal and 2,396 of Cape Colony, remarks that these "facts. lead him irresistibly to the conclusion that a new era in the history of Rhodesia has already commenced. The railways have more than fulfilled my most sanguine expectations, and their future is assured.'

The British Gold Coast railway through Ashanti, with its route through a tropical belt between $4^{\circ}$ and $8^{\circ}$ north latitude, is being constructed at the rate of 6 to 7 miles per month. This road will be 126 miles in length with a gauge of 3 feet 6 inches, which is the "standard South African gauge." The contractors 
at first had difficulty in securing the necessary labor, but since they have won the confidence of the natives they have experienced little difficulty in keeping up a force of laborers numbering i 5,000, whom they pay aboùt 30 cents a day.

The labor question has reached an acute stage in all parts of Africa. Lord Milner has asked for permission to import 10,000 Indians, to be employed exclusively in railway construction and to be repatriated at the end of ten years. The limitations regarding employment and repatriation are intended to overcome a deep-seated opposition to "Asiatics" in South Africa. Secretary Chamberlain expressed himself (July, r903) as unwilling to grant Lord Milner's request until he could be assured of strong local support in the undertaking. At a notable Boer conference during midsummer, attended by representatives of all classes, General Botha expressed the conviction that the labor supply of the country was inadequate for its agricultural and industrial development, and that it might become necessary to resort to the importation of Asiatics.

While the British have done most to develop railways in Africa, other nations have not been inactive. During the first quarter of 1903 the German Reichstag appropriated 750,000 marks for the continuation of the Usambara line from Korogwe to Mombo, in German East Africa. One member of the Reichstag spoke in favor of the bill because he feared aggressive competition on the part of the Uganda railway, the eastern terminus of which is only roo miles north from that of the Usambara line; another, because the railway would open up other parts of Usambara territory to agriculture and planting; and a third member favored the appropriation because he regarded the railway in the light of an experiment which would prove whether the colony really had any value. Traffic on this road has been ridiculously light. The estimated receipts for 1903 are 156,700 marks, against expenditures amounting to 346,682 marks, or a deficit of 189,982 marks. The number of colored passengers has been ten times the number of whites, and the amount of paying freight one-eleventh of the free freight in the form of materials for construction and government supplies.

The governor of German Southwest Africa reports that the most important question in the protectorate under his charge is 
that of railway construction, and that railways must precede, not follow, economic development in the colonies, a principle which railway pioneers in the United States and Australia have long recognized. In October, I899, the German government and the British South African Company entered into a treaty for the construction of a railway connecting the Rhodesia main line with the west coast, and more recently the Otavi Mines and Railway Company has projected extensions without which, the German governor says, the copper mines and marble quarries cannot be worked.

Late in 1902 an English syndicate secured the contract for the construction of a railway through Portuguese West African possessions, beginning at Benguella on the coast in latitude $13^{\circ}$ south and extending eastward about 870 miles. In Portuguese East Africa the government has decided to build a new line which will open up new coal fields and reduce the present shortest distance of 396 miles between the coast and Johannesburg by way of Pretoria by 60 miles. The next shortest route is from Durban, $483 \frac{1}{2}$ miles, followed by the route from East London with 688 miles, from Port Elizabeth $7 \mathbf{5}$ miles, and, finally, from Cape Town I,OI 5 miles.

On January I, I903, the Imperial Ethiopian railway was opened as far as Adis Harrar, 308 kilometers from the French port of Jibuti. This is still 500 kilometers distant from the final terminus at Adis Abeba, the capital of Abyssinia, a charter for all of which was granted by King Menelek as early as I 894 . While the Italian invasion interrupted the work, it called attention to the "great potentialities" of the country, and in February, I90I, the government of French Somaliland granted the Ethiopian company an annual subsidy of $£ 20,000$ for fifty years. Various opinions are current with respect to the ultimate economic success of the enterprise. A correspondent of the London Times, who passed over the route in the spring of $190_{3}$, describes the territory traversed by the line as "endless expanses of stones, of every form and shape and color, gorges without water or verdure, vast plains covered with scrub and thorns, but neither trees, nor crops, nor villages, nor signs of animal life, or, indeed, of permanent insect life other than the innumerable ant-hills.' King Menelek has also promised Lord Cromer permission to connect the Soudan with Uganda by means of a railway through Abyssinian territory; 
and plans for the construction of a line from Khartoum to the Red Sea, via Suakim, following the caravan routes, have been elaborated by Lord Cromer and the Sirdar.

Belgian authorities have sent engineers to Congo State to do preliminary work on a line from Lake Kisali toward the Rhodesian frontier to connect with one of the Cape lines.

It will thus be seen that in all parts of Africa the railway is wresting ground from the caravan and cart. Live calves carried I 75 miles in sacks hung over the backs of mules; the camel and the donkey and the two-wheeled cart as active competitors for freight and passenger traffic will soon be things of the past. The Cape to Cairo railway, like the mid-rib of a leaf, joined with numerous east and westward branches terminating in its ocean margin, will soon carry over the whole of the once Dark Continent the life of modern civilization and build up empires of wealth and culture.

No single enterprise has in recent years achieved greater international importance than the Bagdad or Anatolian railway. The first 90 miles of this gigantic project of 1,500 miles of railway between the Sea of Marmora and the Persian Gulf were constructed by the Turkish government during the seventies of the past century. In I 888 a German syndicate purchased the lines as far as Ismid, and secured a charter for its extension. During the next four years the line was extended to Angora, the seat of the Galatians, to whom St. Paul addressed his epistle. In 1896 the main line was opened for traffic to Konia, and on July 27 , I903, construction was resumed on the succeeding section from Konia to Ereglia-the entire route being divided into sections of about 200 kilometers each. Thus far the Germans have borne by far the greater part of the financial burden, although French capitalists have lent substantial aid. In their attempts to interest English and other capitalists the Germans have met with unexpected opposition. Early in 1903 the British Prime Minister stated in Parliament, in reply to questions, that no formal communications between the British and foreign governments had taken place, although the subject had been referred to in two brief conversations, one with the French, and the other with the German Ambassador, about a year ago. So far as he knew, Mr. Balfour said, these had had no "results," nor had these conversations exercised any influence. The remarks of the Prime Minis- 
ter called forth a debate of some length in the House of Commons, in which the Bagdad railway was represented as distinctly a German enterprise which would injure existing English railways, and, in general, threaten English supremacy in the Persian Gulf. Led by the London Times, English public opinion gradually veered from an attitude of solicitude for investment opportunities to doubt concerning the whole project, terminating in strenuous opposition to it. Conflicting reports were circulated regarding the relative amounts of stock to be allotted to the different nationalities. Earlier reports gave France and Germany 40 per cent each, leaving 20 per cent for all others; later it was said that England, France and Germany were to receive 30 per cent each and all others together only ro per cent. Meanwhile the Times continued its opposition, with the result that English capital was made to feel that under no circumstances could it participate in a project so prejudicial to legitimate British interests. England was displeased because the head of the Deutsche Bank was elected president, and the director of the Ottoman (French) Bank vicepresident of the Bagdad Railway Company. Provisions of the concession were quoted to demonstrate the dominating influence of the German and French. At Constantinople, it was related, the London Times and Punch had been superseded by Die Fliegende Blätter and the Kolonische Kreutzzeitung in reading-rooms and hotels. French participation was explained on selfish grounds, for her two railways in Asia Minor would be greatly benefited through connection with the Bagdad line. Russia, in the words of $\mathrm{M}$. Witte, regarded the project as a "serious affair, to which the attention of all Europe ought to be directed,"' and maintained an apathetic and even hostile attitude. "If French savings are engulfed in this bottomless pit," $M$. Witte is reported to have said to the manager of La Patrie of Paris, "if thousands of subscribers are ruined, Russia will certainly be blamed.' Russia has been openly opposed to the Bagdad railway, and her Minister of Finance regards it as a "dream which will never be realized." Germany, on the other hand, says the thing will be done and in the near future, too, whether English and Russian capital participates or not. The Porte has agreed to deliver to the company 4 per cent bonds to the amount of $26 \mathrm{r}$, r rof. for each kilometer of road, and the Germans can command the rest. The German 
press naturally regards all this opposition as unwarranted and unjust, and as only another indication of English and Russian dislike for Germany. They characterize the railway as a great civilizing agent, Kulturwerk, in the benefits of which all nations may share alike. They maintain that diplomacy has been resorted to because in Turkey private interests must be backed by diplomacy in order to receive considerate treatment, and that Germany does not care to deal single-handed with the Sick Man. They describe the Bagdad railway as a private financial undertaking, international in character, in which foreign capital is invited to participate. And with the view of giving still further expression to the international character and the economic and political neutrality of the enterprise, a Swiss city has been selected as the seat of the principal office of the company. Antecedents for international projects of this kind, the friends of the railway say, are found in the Danube and Sanitary Commissions, and the Dette Publique. At all events it seems reasonably certain that the entire line will be constructed, reducing the time between London and Bombay to $\mathrm{I}$, and possibly 9 days, and gradually restoring Mesopotamia to its ancient economic importance.

Everything that Russia and England allege Germany will do by means of the Bagdad railway if she is given a free hand, Russia has already accomplished through her Siberian railway. Treaty obligations bound Russia to evacuate Manchuria during the latter part of 1902; but this "evacuation" consisted, in part, of the removal of troops from temporary quarters into permanent barracks erected on the right of way and on ceded lands adjoining railway stations. The latter sometimes cover ten square miles for a single station, and "railway guards to the number of 30,000 or more are significantly called frontier guards." In addition, Russia owns the steamers on the Manchurian streams which flow into Russian waters, and consequently she practically controls all Manchurian waterways as well. M. Witte's report on the importance of the Siberian railway urges a more careful and systematic use of the railway in promoting internal colonization, so that the annual increase of $r, 500,000$ in Russia's population may be planted on the thinly populated but immensely fertile lands of Siberia. Since 1896 the railway has distributed about 200,000 people annually, but this number should be greatly augmented, 
says the Minister of Finance. Traffic in butter, fresh meat, fish, fruit and other Siberian products has approximately doubled during each year since 1898 . A writer in the Russian Economic Review presents statistics to show that the traffic over the Siberian line must increase very greatly if it is to pay expenses. Passenger traffic is likely to increase, partly as the result of a conference, held in Paris in the fall of 1902 , and representing Russian-Chinese lines, three French lines, Dutch, Belgian, German, Austro-Hungarian railways, one English company, and the International Sleeping-Car Company. The conference considered matters relating to through traffic to Dalny, Peking, Shanghai, Yokohama and other places, and designated London, Paris, Brussels, Amsterdam, Berlin, Vienna, Budapest and St. Petersburg as places where offices for the sale of tickets to Oriental points are to be maintained. The present time between the large cities of western Europe and Peking is eighteen to nineteen days, and to Chinese or Japanese ports from two to three days longer, thus shortening the time by from thirteen to fifteen days, or about one month for the round trip, compared with the time consumed before the Siberian route was opened. The expenditure of some twelve millions of dollars has been authorized for Russian railway extensions, and a powerful syndicate of Russian and foreign capitcilists is projecting numerous transverse lines to intersect with the Siberian railway. Financially, the Russian system has not been successful, and the estimated excess of railway expenditures over receipts has been placed at $60,000,000$ rubles, or $\$ 30,900,000$, for 1903 . In a statement reported to have been made before the Imperial Council, the Minister of Finance ascribed this situation mainly to the enforced construction of railways of a political and strategic character during the last decade. The construction of railways which are of economic value, he said, need cause no apprehension, and for a long time to come Russia will have to build several thousand versts annually of this kind of railway if she will hold her own against foreign competitors. "It is quite another question with railways that are purely of political and strategic value, such as the Novoselitz branches of the Southwestern Railways, the strategic lines in Poland and West Russia, the Ussuri and Central Asiatic railways, the southern branch of the Chinese Eastern railway and others. These railways will not, for a long time, pay even the 
interest on the capital laid out in construction; some do not even cover working expenses." The minister of public works has taken steps to remove the causes of the numerous complaints entered in the "books of complaint" kept at stations for the use of the traveling public, and to eliminate other evils in the administration of railways. The complaints relate to the time for opening and closing ticket offices, untidy coaches, theft of hand baggage, inadequacy of compartments for women, etc. Train robberies are a common occurrence. Recently a passenger was drugged, carried from the coupé which he had originally entered, into an unoccupied one, and there he was robbed. Accounts have also been published alleging the existence of gross corruption among Russian railway employees. Higher officials are charged with collecting regular monthly payments from their subordinates, who in turn exercise a free hand in reimbursing themselves, much after the fashion of certain metropolitan policemen in the United States. An influential railway journal finds extenuating circumstances for this thievery in the starvation wages paid to many employees, but the real explanation it finds in the deep-seated notion of the Russian people that there is nothing wrong in robbing the public treasury.

The past year in the railway world of China was, what it will probably continue to be for years to come, a period of international rivalry in securing privileges and concessions. The concession granted in June, I902, to the American-China Development Company, Rear-Admiral Evans, writing from the Asiatic naval station, regards as "the most important single interest we now have in this section of China." This is a line about 700 miles in length, between Canton and Hankow, over a route which Chinese traders between the North and South of China have for centuries followed, and along which numerous large commercial cities have grown up. The company started with a paid capital of $\$ 3,000000$ in gold, and is authorized to issue bonds guaranteed by railway property to the extent of $\$ 40,000,000$ gold, bearing 5 per cent interest. The concession is for eighty years, when it reverts to the Chinese government on payment of the market value of the stock, but the government reserves the right to purchase it on the same terms at any time after forty years. Efforts are being 
made to complete the railway in three years. The management of affairs is entirely in the hands of Americans.

The German-Chinese Railway Company, embracing the Deutsche Bank, Dresdner Bank, and ten other strong German financial institutions, was incorporated in Berlin with a nominal capital of $\$ 2,500,000$, for the purpose of financing Chinese state railways. The Russo-Chinese Bank raised a loan of 40,000,000 francs in Paris for the construction of the Ching-Tai railway, a western branch of the Lu-han railway, the trunk line between Hankau and Peking in which French and Belgian capital is heavily interested. In June, I903, the British government asked China to grant to the Peking Syndicate railway a guarantee of 5 per cent on the same terms as had been granted to the RussoChinese bank for the Ching-Tai railway. At the same time England asked for "favorable running powers' over certain railways, a share in the concession for the Yen-Pu railway, and "preference" in providing capital for the Hu-pei-Sze-Chuan railway in case the assistance of foreign capital is required. In a word, the railway problem in China is, to-day, primarily a question of maintaining a modus vivendi between competing foreign capital.

A report of a special commissioner to the Secretary of State for India, published in March, 1903, condemns the present mixed railway system generally, but not the men who do the work. "The present administration and working of the Indian railways cannot be regarded as at all satisfactory. But $I$ attribute this more to the system than to any individual action on the part of the railway or Government officers." The commissioner favors the leasing of all state railways to companies. He recommends that the control of Indian railways be vested in an independent board, presided over by a member of the Viceroy's Council. He urges cheaper fares and quicker traveling at lower rates, which will add to the commercial and financial success of the railways and increase the prosperity of the people as well as the popularity of the government. Somewhat different in tone were the statements made by Lord Hamilton when he presented the Indian budget to Parliament. For many years, he said, the Indian railways had been worked at a loss, but during the last three years there had been a remarkable increase in the receipts. During the entire

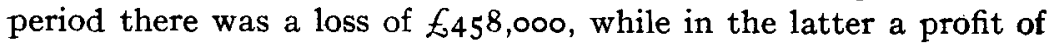


£795,000 had been realized, which was the more noteworthy because the earlier railways traversed the richer and more densely populated territory, while later lines were laid through the poorer districts, many of them quite as much for military as for other reasons. "We can count on the Indian railways producing an increasing source of income for years to come." During June, I903, articles in the London Economist stated that although two of the Indian state railways had suffered a serious decline in net earnings, the others had fairly maintained their previous position. Traveling of natives is largely for the purpose of pilgrimages, attending religious festivities and fairs. The plague interfered with these events, which resulted in an appreciable decline in the revenues from third-class passenger traffic.

Legislation providing for a great transcontinental railway is the most important recent railway event in Australasia. The transcontinental railway act was passed in November, I902, and bids for the construction of the line will be received until May 2, I904. Americans are competing for the contract. The projected railway extends from Oodnadatta, in South Australia, to Pine Creek in the Northern Territory, closing the gap between Adelaide and Port Darwin on the south and north coasts respectively. The existing line between Adelaide and Oodnadatta is 688 miles in length, and that from Port Darwin to Pine Creek $145 \frac{1}{2}$ miles, which, together with the projected connecting line of 1,200 miles, will bring the total up to about 2,000 miles, or approximately equal to the distance between the head of Lake Superior and the Pacific coast. The road will be built on the land-grant plan, the amount of the grant not to exceed 75,000 acres for each of not more than I,200 miles of road, in alternate blocks on either side of the railway. The gauge of the new road is to be 3 feet 6 inches, this being the gauge for over 8,000 miles of existing Australasian railways, while over 3,000 miles have adopted the standard gauge of 4 feet $8 \frac{1}{2}$ inches, and nearly 4,000 miles have a gauge of 5 feet 3 inches. The Australian transcontinental line will probably co-operate with the Siberian line in competing for traffic with allocean routes.

Of supreme importance from a political and social point of view was the Victorian railway strike of May, 1903 . The Victorian railways, like those of the rest of Australasia, are owned and 
operated by the state, and this strike in its last analysis involved the question whether organized labor could rebel against the power of the state. A firm Premier strongly supported by his colleagues, backed by public opinion, promptly asserted the sovereign power of the state and the supremacy of the laws of the land over the rules and acts of labor unions. The attitude of the government was essentially similar to that recently maintained by President Roosevelt in dealing with the government printers at Washington. There are those who believe that if the Victorian government had been in the hands of weak men, the result might have been disastrous to the government.

In South America, the Transandine project plays the rôle of transcontinental railway. The termini are Buenos Aires and Valparaiso, and, when completed, will reduce the time between these two cities to forty-eight and possibly to thirty-six hours. The Argentine section of the line is completed to within 200 metres of the point where the Andean tunnel is to begin, but it may be several years before the Chilian section will be ready, although the present terminals are only a day's journey apart. The geography of the country has made Chilian railway progress in general difficult. The longitudinal extent. of the country is 2,629 miles, with an average width of IOI miles. "Chili at the Pan-American Exposition," I 901 , records I,430 miles of private and I,420 miles of state railways. The government is aiming to develop a strong longitudinal line running north and south with transverse branches connecting it with the coast.

Consolidation has been the most important movement in Argentine. According to La Prensa of Buenos Aires all the broad-gauge railways of Argentine, embracing eight companies with a total mileage of 6,300 and $\$ 350,000,000$ capitalization in gold, are to be combined. Important consolidations have already been effected, and only time can tell whether the entire program will be completed. The Argentinian railways have experienced difficulties similar to those frequently encountered by our western roads during crop-moving seasons, especially the last; and the Board of Ways and Communications has established offices in each of nine different agricultural regions for the purpose of investigating complaints. A government inquiry attributed the 
delays in grain shipments chiefly to the inadequacy of terminal facilities rather than a deficiency in rolling stock.

Brazil purchased over 2,000 kilometers of guaranteed railways by the issue of "Railway Guarantee Rescission Bonds," effecting an annual saving in interest charges of $£ 247,55^{\circ}$, this being the difference between the interest on the bonds and the amount of the former guarantee. In addition, it is estimated that leasing the acquired lines will yield $£ 125,000$ more.

Bolivia and Argentine entered into a convention for the construction of a line from Jujuy, about I 25 miles south of the boundary line between the two countries, into Bolivian territory. For the present, Argentine will construct and own also the Bolivian section, but the latter country reserves the right of repurchase under specified conditions. Another convention between Argentine, Bolivia and Chili governs the through passenger traffic. Bolivia has constructed its first state line from Lake Titicaca, said to be the highest navigable body of water in the world, to La Paz, a distance of 57 miles.

The Colombian National Railway Company has already completed 86 of the 3 i 6 miles of railway between Bogota and Buenaventura on the Pacific, a route which, it is expected, will largely supersede the customary avenue of approach to Bogota, from the Atlantic side, by way of the Magdalena River and three short railways. Both routes are important and the Isthmian Canal is likely to greatly enhance their value. The Colombian government gives liberal land grants and devotes to per cent of its customs revenues to railway purposes.

The governor of a northeastern province of Peru, a famous explorer, has discovered the possibility of a more northerly railway across the Andes, and plans are well under way for the construction of a road which will connect the Pacific with the Amazon. From the Manseriche Falls of the Amazon a line is also to be extended southward to Cerro de Pasco, in central Peru, from which a railway is now in process of construction to Oroyo, about roo miles northeast of Lima. Important electric lines have been projected in Peru. Two companies have secured concessions for sixty-six years, freedom from taxation, and free importation of materials for two years. At the end of sixty-six years all the property is to revert to the government free of cost. 
Having taken a survey of recent railway. events in the less developed areas of the earth, it will now be in order to remark briefly concerning the more advanced countries, beginning with England, the home of the first important railway enterprise.

English railway management has been much criticised of late because of the lack of adequate statistics as a basis for the most successful operation, and also because of adherence to antiquated types of cars and locomotives. A competent Continental European critic has recently characterized English railway statistics as the poorest of any in the civilized countries of the world. Rigid attention to statistical expression of every detail of the business, the employment of statistical units like the ton-mile for cost and the train-mile for revenue, as a touchstone of successful administration, which have made the great success of many American lines possible, are practically unknown in England. The extraordinary economy in operating vast systems like the Hill lines may be attributed largely to what may be called a statistical consciousness of every branch of the service in its remotest details. Minority stockholders of English railways have made formal protests against antiquated methods, and railway publicists like Acworth and Paish have revealed the situation in its scientific aspects. The recent increase in dividends on common stock has been attributed largely to improved managemont. The "Americanization" of English railways is regarded as an impossibility by officials, who emphasize the important differences between Engiish and American traffic, characterizing the former as "retail" and the latter as "wholesale" business. Because of the smallness of the "average" load of freight, large cars of twenty to fifty tons capacity, which are constantly increasing in number on American roads, are regarded as impracticable and expensive; and the experiences of English roads with cars of twenty tons capacity are cited to prove the point. A distinguished American railway expert thinks that the inferior size of the heavy stone arches, which would not admit of the passage of forty-ton cars and corresponding locomotives, is the greatest obstacle to the introduction of the American type of equipment. However, calculations have been made which show that the freight carried in $45^{8}$ ordinary London and Northwestern cars could be carried in 322 thirty-ton American cars, but that the tare weight would rise to 
4,669 tons as compared with 2, I 99 tons for the English equipment. In other words, considering the retail nature of the English traffic, the expense of terminals, and the custom of railway delivery of freight, a gradual modification of existing equipment with the view of increasing paying loads is preferable to the substitution of American types of equipment and methods of management. At least, that is what the majority of English officials are saying.

French railway statistics, too, have been under fire. While they exhibit definite facts regarding the quantity of traffic, revenues and expenditures, they fail, in the estimation of their critics, in revealing the true financial situation. As is well known, the French government, by the terms of the "conventions"' of 1883 , pays heavy guarantees and subsidies to her railways, although when the conventions were drawn glowing prospects of handsome profits to the state were held up to view. Only one of the great railways has paid anything, and that an inappreciable sum, to the state as its share of the net profits, while the aggregate indebtedness of four of the companies, January I, I90I, was nearly one thousand millions of francs. The debates in the Assembly on the budget gave indication of an awakening of public opinion in regard to the railway question, and in the not distant future it may become a topic of intense discussion. The labor leaders have charged the minister with opposition to the "syndicates" of railway employees, as well as with inefficiency and mismanagement. The labor question was injected into the debate partly as a result of the railway strikes in Belgium and Holland, and the declaration of the Prussian minister of public works that no employee can be a social democratic agitator and retain his position, that final authority cannot at the same time reside in labor unions and in the minister, and that as long as he was minister, authority shall remain in the department of public works.

Prussia, the classical illustration of an efficient system of state railways, absorbed six more private companies during the year, operating about 570 miles of road. This leaves only about I,3 I 2 miles of primary and secondary railways still in private hands. Of the six newly acquired lines, four are secondary roads, lying in less developed agricultural regions. The same causes which have increased railway expenses in the United States have operated similarly in Prussia, resulting in a slight decrease of net 
revenues-the estimated decrease for 1903 is $\$ 1 \mathrm{I}, \mathrm{I} 86,000$-but still yielding a clear surplus of about $\$ 130,000,000$, or nearly $6 \frac{1}{2}$ per cent on the investment. Among the advantageous changes introduced during the year, the minister enumerates the declassification of a large number of commodities; reductions in rates on ores, coke, fertilizers, cattle and agricultural implements; special export rates on iron and steel; and arrangements for the prompt conveyance of commodities endangered by early frosts. Multifarious demands beset the railway manager in Prussia as elsewhere, as the following quotation from the minister's address in the Herrenhaus will show: "One person wants a new but unprofitable road; another desires additional trains; another better upholstering for second-class coaches; still another, new appliances, electric light and what not. . . . The demands . . . are increasing, but notwithstanding a reduction in rates is requested at the same time. Those who demand 'tariff reform' always mean reductions. . . No congress assembles but what its delegates request free transportation, no Sängerfest but what the Sangesbrïder think they are entitled to free rides. This means that the cost of transportation is thrown on the wrong shoulders; song does not belong to railway administration

From a scientific point of view the most notable event in Wuirttemberg was the attempt to arrive at the cost of service in the passenger traffic. A protracted agitation and discussion in the legislature of reforms in railway rates was the occasion which prompted the renewal of an attempt which has hitherto been made by others with little success. The reduction of the aggregate passenger service to average trains was followed by an analysis of the services of an average "limited" train with respect to trainkilometers, axle-kilometers, occupied and unoccupied seats for the different classes of coaches. Similarly, other classes of trains were analyzed and the elements of cost in motive power, maintenance and renewals, and miscellaneous items, reduced to corresponding figures. The railway authorities believe that this investigation demonstrates the impossibility of lowering passenger rates without throwing the burden of a deficit in this upon other branches of the service, and that future progress must lie in the direction of quality of service rather than reduction of rates. The debates on the railway budget gave evidence of grievances which members 
of the legislature feel towards Baden for alleged deflection of traffic to Bavaria over more circuitous routes to the direct loss of millions of marks to Württemberg. Illustrations were given to show that the arbitrary routes exceeded the natural ones by from 30 to 40 per cent in direct violation of the federal constitution which commands the operation of railways as a uniform network in the interests of the general traffic.

Saxony has experienced a year of agitation for "reform," both with respect to internal and through traffic, in which the relation of Saxon railways to other systems is an important consideration. There has been more or less talk concerning closer affiliation with the Prussian and other foreign systems, not only in Saxony, but also in Baden, Wirttemberg and other states. Soon after his appointment, the new Prussian minister visited the capitals of the federated states for the purpose of promoting greater cooperation among the railway administrations within the empire. The predominant influence of Prussia makes an unreserved understanding with other administrations quite essential, but there are no indications of a formal consolidation of the various systems on account of financial as well as political reasons. Better voluntary co-operation is the only practicable plan at present. Among the other notable events in the German railway world should be mentioned the contemplated creation of a Bavarian department of public works, and the quarter-centennials of the German " $\mathrm{Re}$ form tariff" and "Tariff Commission."

The practical downfall of the original zone system marks a turning point in the railway policy of Austro-Hungary. The zone tariff of $\mathrm{I} 889$ was "revised backward"' in $\mathrm{I} 894$ and $\mathrm{I} 896$, and on January I, I903, radical modifications of the system were introduced into the Hungarian tariff, which leave the term "zone tariff" as a "name without content and without significance." The wider zones of the original tariff were found to influence the movement of passengers and the revenues of the railways unfavorably, so two new zones were added and the width of the first five reduced to $10,5,5,7$ and I 3 kilometers respectively. This makes it a zone-distance tariff, of which numerous illustrations can be found in the United States, and which, with still greater modifications and local adaptations, has been proposed for Sweden. Distance is disregarded only beyond the 400 kilometer line, where 
the traffic comprises less than I per cent of the total. Financial considerations compelled Austria to advance her zone rates in $\mathbf{1 8 9 2}$, I895, and January $\mathbf{I}, \mathbf{I} 903$, the last advance being I 2 per cent on primary, 6 per cent on secondary, and 3 per cent on local railways. Russia's experiments with the zone system since I 894 compelled her to make advances in rates in April and October, 1902; and since 1896 Denmark has been trying a similar system with the result that passenger mileage has increased 60 per cent, but an annual deficit in the railway budget of $\mathrm{I} 4 \mathrm{I}, 000$ crowns. has been incurred.

The Italian government entered into sixty-year contracts with operating companies on July I, I885, with power to terminate the contract at the end of twenty-year periods, on two years' notice by either party. Notice to abrogate existing contracts was given by both parties on April 28 , 1903 , and the period intervening before the expiration of the contracts on June 30, 1905, will be absorbed in investigations and negotiations. The government commission for the study of the railway problem hopes to complete its work before January I, I904. Dissatisfaction with present conditions is universal. Passengers complain of vexatious delays and general irregularity. Shippers chafe under rates alleged to exceed those of surrounding countries by 25 to 30 per cent, not to mention lack of cars and intolerable slowness. in speed. Railway employees are discontented because the companies have failed to live up to the terms of their contracts with respect to hours, wages and holidays. Lastly, the government is dissatisfied because, contrary to the anticipations of $188_{5}$, the state has not only received no financial benefits, but it has been compelled to make up deficits which, since 1895 , have exceeded $\$ 40,000,000$ annually. This situation has naturally developed three divergent views concerning the future of Italian railways. The first party favors the introduction of a purely private system of railways and the sale of government railway property to privatecompanies. The second advocates the introduction of a state system like the Prussian. The third believes in readjustment of the present contractual relations between the railway companies. and the state and a continuance of government ownership with private operation, and the introduction of profit-sharing with. railway employees. 
The remaining countries of Europe may be passed over briefly. Sweden is perfecting plans for the introduction of electricity on one of her railways as an experiment, in accordance with the special report on this subject submitted to the King in December, I902. Experiments of this kind are being made in nearly all parts of the world, one of the most interesting features of which is the operation of single motor cars as day coaches or sleepers where the traffic does not warrant a regular steam locomotive train or where such a train could only be operated at a loss. Sweden is also trying the utility of advisory councils. If the experiment is not satisfactory, the council will cease to exist in 1904 by the terms of the royal decree which created it. The Ofoten railway, "the most northerly railway" in the world, was provisionally opened in November, 1902, while the formal opening took place during July, I903, in the presence of royalty and representatives of the domestic and foreign business world. British capital persisted in constructing the road in order to supply England with Swedish ore all the year round, which this railway, running into an Atlantic port, makes possible. Thus "the long and severe winters of the Arctic are being conquered and the Baltic winter defied." One of the two new railways opened in Finland lies in the region north along the Gulf of Bothnia. Denmark is considering a reorganization of her railway administration by the appointment of a general directory subordinate to the minister of public works, composed of three persons representing the technical, operating and traffic departments, respectively,

Nothing has been said about the new Canadian transcontinental lines, because the facts regarding them are generally known, and for purposes of this essay, Canadian railway events can scarcely be looked upon as "foreign."

B. H. Meyer.

University of Wisconsin. 